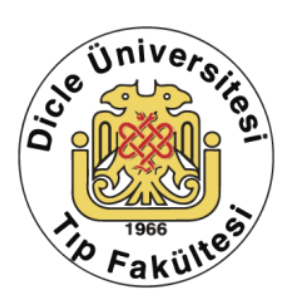

\title{
The Investigation of the Relationship Between Semen Analysis and Doppler Ultrasonografic Findings of Reflux Flow in Patients with Subclinical Varicocele
}

\author{
Ahmet Vural ${ }^{1}$, Mustafa Salih ${ }^{2}$ \\ 1 Dept. of Radiology, University of Health Science Fatih Sultan Mehmet Training and Research Hospital, Istanbul, Turkey ORCID: 0000-0003-1009-973X \\ 2 Mustafa Salih Imaging Center, Ankara, Turkey ORCID: 0000-0001-8039-8239
}

Received: 20.03.2019; Revised: 30.09.2019; Accepted: 07.10.2019

\begin{abstract}
Objective: The aim of the present study was to the measurement of reflux flow volume, velocity and duration with color doppler ultrasonography (CDUS) in subclinical varicocele cases, and comparison of CDUS findings with semen analysis.

Method: 219 infertile men with no clinical overt varicocele are examined with CDUS. 61 people who have vein diameter bigger than $2 \mathrm{~mm}$, or have 1 second or longer reflux flow were classified as subclinical varicocele. CDUS examination is implemented in decubitus position. Reflux flow volume, velocity and duration of reflux in plexus pampiniformis veins were measured bilaterally during Valsalva maneuver.

Results: In subclinical varicocele cases, mean vein diameters were measured mean $2.35 \mathrm{~mm}$ while resting, and 2.61 mm during Valsalva maneuver. With Valsalva mean reflux flow volume was $13.56 \mathrm{~mL} / \mathrm{min}$, duration was $1.32 \mathrm{sec}$, flow velocity was $5.6 \mathrm{~cm} / \mathrm{sec}$. There were anomaly in semen analysis of 13 of these cases (21.3\%). A significant correlation between reflux duration and reflux flow velocity are found. However, no significant relation between reflux flow volume, velocity and duration with semen analysis is detected.

Conclusion: In subclinic varicocele cases, CDUS is a valuable diagonistic procedure that is quite successful on detecting the vein diameter and reflux. No relation was found between reflux flow volume, velocity and duration with semen analysis. However, a study commited with a larger group could give more useful information.
\end{abstract}

Keywords: Varicocele, Color Doppler Ultrasound, Infertility, Semen Analysis 


\section{Subklinik Varikosel Olgularında Semen Analizi ile Reflü Akımın Doppler Ultrason Bulguları Arasındaki İlişkinin Araştırılması}

Öz

Amaç: Fizik muayene ile tespit edilemeyen subklinik varikosel olgularında renkli Doppler ultrasonografi (RDUS) ile reflü debisi, akım hızları ve akım sürelerinin ölçümü, RDUS bulgularının semen analizi ile ilişkisini araștırmak.

Yöntemler: İnfertilite bakımından araştırılan ve klinik olarak varikoseli olmayan toplam 219 olguya renkli Doppler US incelemesi yapıldı. Ven çapları 2 mm'den büyük veya 1 sn ve daha uzun süreli reflü akımı bulunan 61 kişi subklinik varikosel kabul edilerek incelemeye dahil edildi. Bu olgularda RDUS incelemesi sirtüstü yatar pozisyonda uygulandı. Her iki tarafta pleksus pampiniformis venlerinde istirahatte ve Valsalva manevrası esnasında reflü debisi, akım hızı, akım süresi ölçüldü. Subklinik varikosel olgularında semen analizindeki anormallik ile RDUS incelemelerinde tespit edilen reflü debisi, akım hızı ve akım süreleri arasında ilişki varlığı araştırıldı.

Bulgular: Subklinik varikosel olgularında ven çapları istirahat halinde ortalama $2.35 \mathrm{~mm}$, valsalva ile $2.61 \mathrm{~mm}$ ölçüldü. Valsalva ile ortalama reflü debisi $13.56 \mathrm{~mL} / \mathrm{dk}$, akım süreleri $1.32 \mathrm{sn}$, akım hızları $5.6 \mathrm{~cm} / \mathrm{sn}$ bulundu. Bu olguların 13 ünde semen analizinde anormallik mevcut idi $(\% 21,3)$. Reflü süresi ile reflü akım hızları arasında anlamlı korelasyon bulunmuștur. Ancak reflü debisi, hızları ve süresi ile semen analizleri arasında belirgin bir ilişki tespit edilemedi.

Sonuç: Subklinik varikosel olgularının tespit edilebilmesi için RDUS değerli bir tanı yöntemi olup ven çapı ve reflünün tespitinde oldukça başarıldır. Reflü debisi, akım hızı ve reflü süresi ile semen analizi arasında anlamlı ilişki bulunamamıştır. Ancak daha büyük bir grupla yapılacak çalışma daha faydalı bilgiler verebilir.

Anahtar kelimeler: Varikosel, Renkli Doppler Ultrason, İnfertilite, Semen Analizi.

\section{INTRODUCTION}

Varicocele is defined as "The veins are swollen and twisted over the testicle, which becomes smaller" by C. Celsus in the first century AD, while it's defined as "having reflux in the venous flow and result of spermatic vein that composes pampiniform plexus which drains the testicles, becoming elongated, dilated and tortuous" nowadays ${ }^{1,2}$. While varicocele is seen in almost $15 \%$ of the general men population, infertility is found in $20-40 \%$ of men. Most of the idiopathic varicoceles are found on the left side or can be seen bilateral lesser. Isolated right varicocele incidence is quite a few (less than $2 \%)^{3-5}$. Even the direct relation between varicocele and infertility is not clear, its connection with a decrease in testicle volume and deterioration on semen analysis are documented $^{6}$. Nevertheless, a considerable amount of men with varicocele have no infertility problem ${ }^{6}$. Therefore, even the surgical treatment of varicocele causes discussions occasionally, current data show that varicocele treatment causes critical recovery in semen parameters and significant increase in pregnancy rates as a result of ${ }^{7-9}$.

Varicocele is clinically diagnosed with a physical examination. Physical examination should be executed in a warm room ${ }^{10}$. However, the specificity of physical examination on varicocele diagnosis is only around $70 \% 3,11$. On the other hand, CDUS has $97 \%$ sensitivity and $94 \%$ specificity on revealing varicocele ${ }^{11}$. CDUS has taken venography's place that was accepted as a golden standard on varicocele diagnosis because it is not invasive like venography ${ }^{11}$. Varicocele is the most common reason for secondary male infertility11-13. Thusly, in infertile cases, scrotal CDUS is frequently used to examine varicocele existence. There are no exactly accepted criteria for diagnosing varicocele with CDUS. By using ultrasound, 
many researchers used parameters such as measuring vein diameters while standing ${ }^{14,16}$, or while laying ${ }^{17-19}$, or measuring reflux flow with venous diameters ${ }^{3,20-23}$. These studies generally include heterogeneous groups. Specific values are tried to be obtained for venous diameters and reflux flow on the ones with a clinic, subclinical varicocele or without varicocele $^{3,14,22}$. The purpose of this study is to research the relation between reflux flow volume, velocity, and duration of the subclinical varicocele cases with semen parameters. In this manner, with CDUS examination that is noninvasive, easily applied and gives rapid results, the predictability of anomaly in semen parameters will be evaluated.

\section{METHOD}

In a prospective study, 219 cases that are being researched with pre-diagnosis of infertility, yet not found varicocele with physical examination are implemented CDUS screening. The acceptability criteria for the study are determined as, not having varicocele surgery, not having inguinal herniorrhaphy, not having an important urogenital infection history, and not having intraabdominal mass history. 61 people who have vein diameter bigger than 2 $\mathrm{mm}$, or have 1 second or longer reflux flow were involved into the research accepted as subclinical varicocele. Mean age of the patients is $28.41 \pm 7.07$, age distribution is $19-48$, al the cases that are taken into the study were conducted semen analysis.

In the study, CDUS examinations are performed by only one researcher. CDUS examinations are performed by using $7.5 \mathrm{MHz}$ ultrasonic ultrasound probe with Toshiba Aplio device (Toshiba Medical Systems Corporation, USA). The examination is performed while all of the patients were laying back and by means of being raised 15 degrees from chest and head's horizontal axis. Patient is put to bed with his underbelly fully undressed, and the angle between his legs were as wide as possible.
During the examination, in plexus pampiniformis veins, the biggest diameter measurement on both sides are performed (Figure 1 and Figure 2). Later, flow volume, velocity and duration of reflux were measured during Valsalva maneuver. Measurements are repeated at least three times from each sides for CDUS parameters and means are calculated (Figure 3 and Figure 4).

This study was approved by the local ethics committee (permit no: 13/2017).

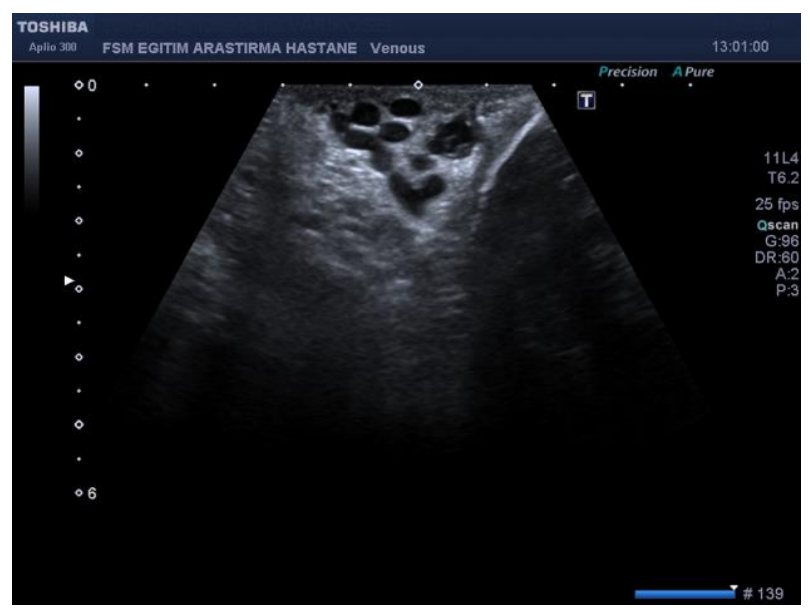

Figure 1. Subclinical left varicocele. Sonographic scan shows a dilated, serpiginous pampiniform plexus.

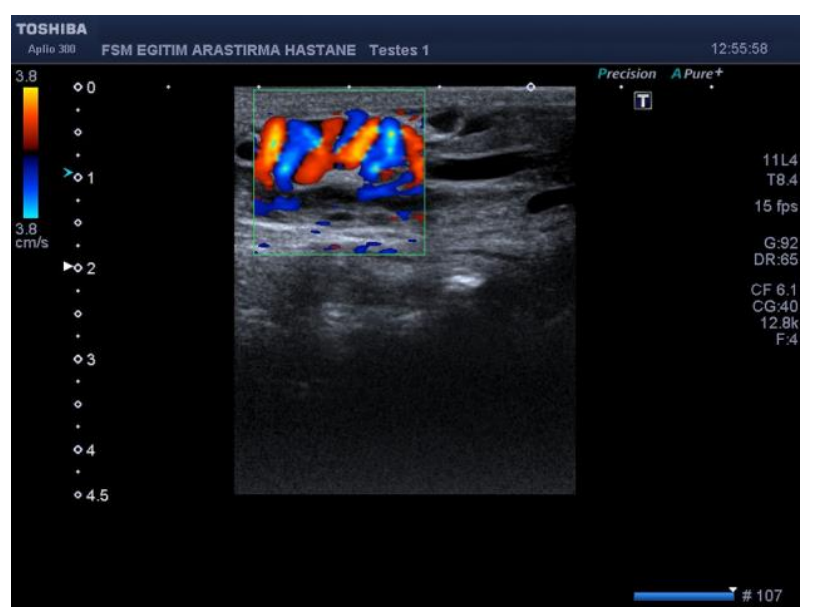

Figure 2. Color Doppler ultrasound of varicocele during Valsalva maneuver. 
Semen analyses were done in the biochemistry laboratory of our hospital with proper sperm samples taken from patients after 3 days of sexual abstinence. Volume was assessed by pipette and weight for all specimens and concentration was determined in a $100-\mu \mathrm{m}$ hemacytometer and a $20-\mu \mathrm{m}$ MicroCell chamber.

An improved Neubauer hemocytometer with two counting chambers was used to determine sperm concentration. At least 20 micron depth chambers were used to prevent sperm movement. Wet preparations were counted by laboratory technicians under microscope. In evaluation of spermiogram tests, sperm amount and sperm movements are taken into consideration. In regard to sperm amount, the cases with sperm less than 15 million per milimeter, are accepted as pathological. In evaluation of sperm movements, sperms movements are classifed as a. progressively motile b. non-progressively motile c. immotile. It is evaluated as normal if the sum of $a$ and $b$ groups are more than percent 40 , if less, it is evaluated as pathological $^{10}$.

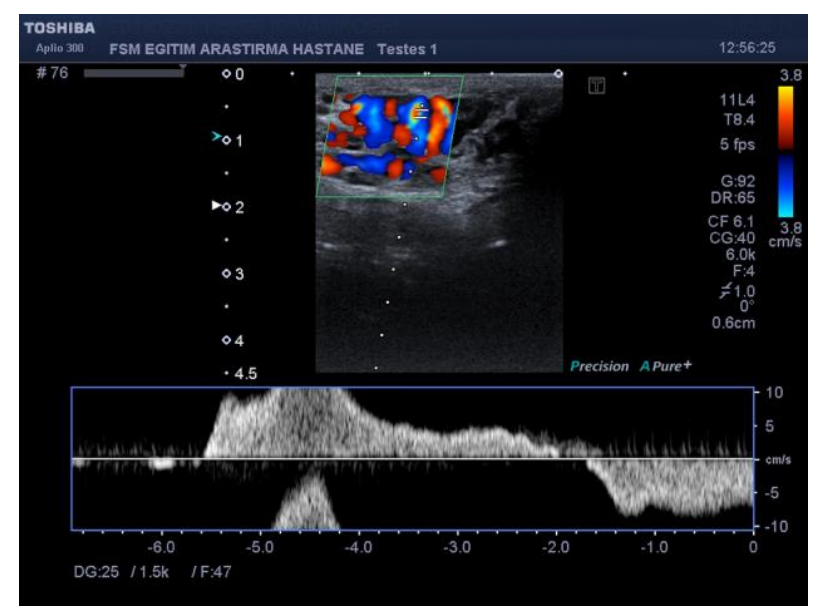

Figure 3. Retrograde flow detected by color duplex and in the Doppler spectrum during Valsalva maneuver is considered as testicular venous reflux.

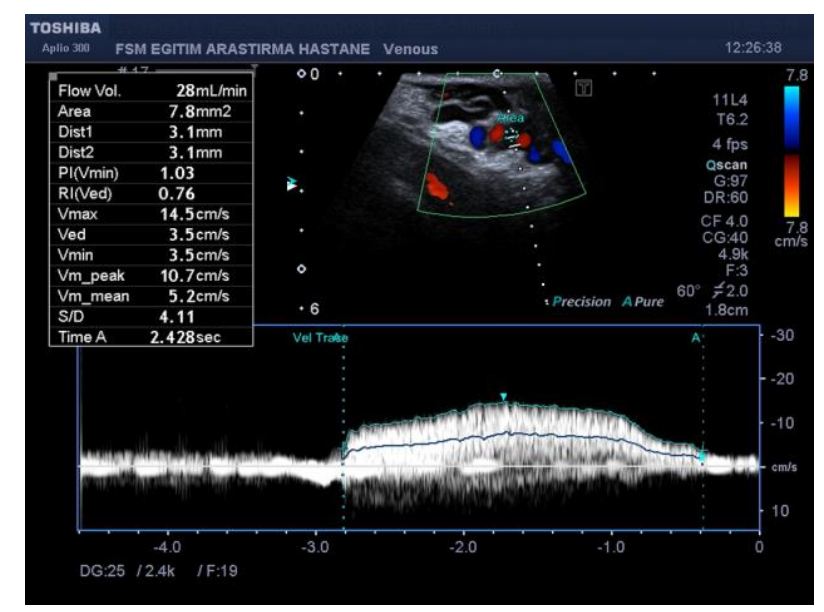

Figure 4. Color Doppler ultrasonography shows reflux duration of $2.4 \mathrm{~s}$, velocity of $14.5 \mathrm{~cm} / \mathrm{s}$ and flow volume of $28 \mathrm{ml} / \mathrm{min}$ in a patient with $3.1 \mathrm{~mm}$ vein diameter.

\section{Statistical Examinations}

For statistical analysis of findings in the study, IBM SPSS Statistics 22 (IBM, SPSS, Turkey) is used. While evaluating the study data, the suitability of the parameters to the normal distrubition is evaluated with Shapiro Wilks test, and it is detected that parameteres don't show normal distrubition. While evaluating the study data, in addition to descriptive statistical methods (Mean, standard deviation), on comparion of the quantitative data, Mann Whitney $U$ test is used. In evaluation of the correlation between reflux flow velocity and reflux durations, Pearson correlation test is used. Significancy is set at the level of $p<0.05$.

\section{RESULTS}

The study is commited on 61 male patients whose ages varies between 19 and 48. Age average is $28.41 \pm 7.07$ years. While the result of spermiogram test of $48(78.7 \%)$ is normal, for $13(21.3 \%)$ of them, it's pathological.

In subclinical varicocele cases, vein diameters were measured between $2 \mathrm{~mm}$ and $3.2 \mathrm{~mm}$ at rest and between $2.2 \mathrm{~mm}$ and $3.3 \mathrm{~mm}$ during Valsalva maneuver. The mean vein diameters were $2.35 \pm 0.23 \mathrm{~mm}$ at rest and $2.61 \pm 0.24$ $\mathrm{mm}$ during Valsalva maneuver. The reflux 
duration with Valsalva were between $0 \mathrm{~s}$ and $2.2 \mathrm{~s}$. The mean reflux duration was $1.32 \pm 0.62$ $\mathrm{s}$. The reflux flow velocity were between $0 \mathrm{~cm} / \mathrm{s}$ and $11 \mathrm{~cm} / \mathrm{s}$. The mean reflux flow velocity was $5.59 \pm 2.9 \mathrm{~cm} / \mathrm{s}$.

The mean reflux velocity of the group with normal spermiogram result was $5.81 \pm 2.80$ $\mathrm{cm} / \mathrm{s}$ and the mean reflux velocity of the pathological spermiogram group was $4.77 \pm$ $3.19 \mathrm{~cm} / \mathrm{s}$. The mean reflux duration of the normal group was $1.34 \pm 0.56 \mathrm{~s}$ and the mean reflux duration of the pathological group was $1.23 \pm 0.80 \mathrm{~s}$ (Table 1$)$.

For correlation between reflux flow velocity and reflux durations, pearson correlation test is implemented, and correlation parameter is found as 0.824 . $P$ value that will show a significant correlation between reflux flow velocity and durations is found below 0.05 .

Table I: Evaluation of reflux flow volume, velocity and duration according to normal or pathological spermiogram test

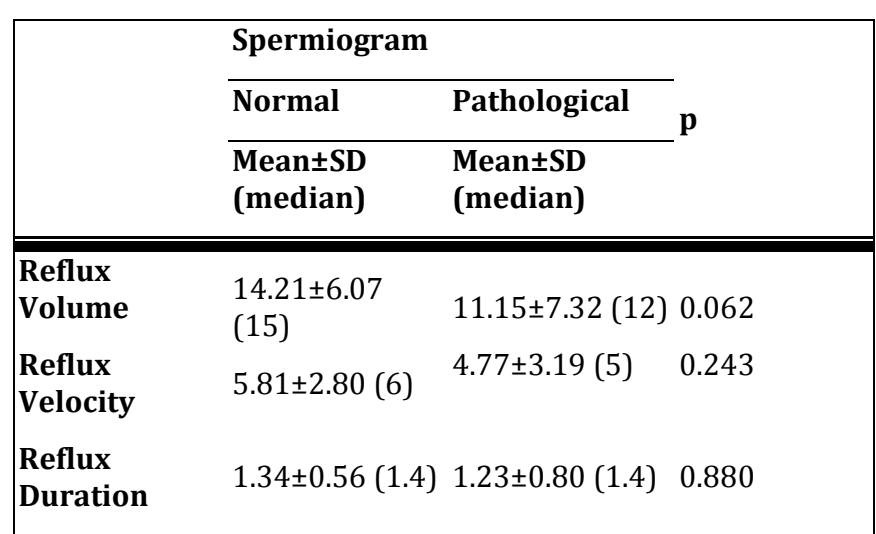

Mann Whitney U Test

There is no statistically significant difference between reflux flow volume, velocity and duration in those whose spermiogram test results are normal or pathological $(p>0.05)$.

\section{DISCUSSIONS}

Varicocele is the most common reason for secondary male infertility ${ }^{12}$. In plexus pampiniform veins, dilatation and concomitant reflux flow are seen. This situation could be determined with the physical examination performed as a routine ${ }^{10}$. During the determination of varicocele with palpation, vein diameter is crucial. In their study, Hoekstra et al. stated that veins that are smaller than $2.5 \mathrm{~mm}$ cannot be determined with palpation, while the veins wider than $3.5 \mathrm{~mm}$ is always determined ${ }^{14}$. Commonly, vein diameter wider than $2 \mathrm{~mm}$ is accepted as varicocele $e^{8,17,24}$.

In their study, Gonda et al. stated that a $2 \mathrm{~mm}$ diameter value is the limit for varicocele diagnosis with 95\% sensitivity ${ }^{25}$. However, vein diameter isn't enough for varicocele diagnosis on its own. Chious et al. did a study where they compared the new criteria that they created with the usage of vein diameter, reflux duration and reflux flow velocity values with Valsalva, and the physical examination. In this study, it is reported that reflux flow velocity is important on scoring in varicocele cases in which there is reflux flow, and it is significant that flow velocity is higher than $2 \mathrm{~cm} / \mathrm{sec}^{26}$. In our study, the mean reflux flow velocity is detected as $5.59 \mathrm{~cm} / \mathrm{sec}$ in the cases with subclinical varicocele. Some studies report almost $60 \%$ recovery in semen parameters with varicocelectomy, and more than $30 \%$ increase in pregnancy rates ${ }^{11,16,27}$. As well as no wide studies were done on this, in subclinical varicocele cases that are not detected with a physical examination, the importance of CDUS examination for determining subclinical varicocele due to the possibility of spermatogenesis response.

The specificity of the physical examination for varicocele diagnosis is only about $70 \% 6,10$. CDUS examination is required for confirming the diagnosis made with physical examination when the sensitivity (97\%) and specificity (94\%) is doubtful ${ }^{11,12,23}$. Also, it enables performing measurements such as reflux flow existence, reflux flow volume, duration, and velocity in pampiniform plexus veins beside the 
measurement of the dilated vein diameters with $\operatorname{CDUS}^{10}$.

In our study, we evaluated a group of 61 cases that are CDUS examined and diagnosed subclinical varicocele in terms of infertility. The relations of anomaly determined in semen analysis and the reflux flow volume, velocity, and durations measured in CDUS examination are investigated. In many studies made on varicocele and infertility relationship and in the studies regarding the effect of the varicocele on semen parameters, vein diameter is used generally as varicocele criteria, ${ }^{28-30}$. In our study, the aim is to reveal the effect of the reflux flow volume, velocity and duration of reflux measured with CDUS in subclinical varicocele cases on semen parameters. However, in the cases that we detected subclinical varicocele, a significant relationship between anomalies in semen analysis and CDUS findings is not revealed. On the other hand, in the infertile cases whose physical examination is normal, for revealing the subclinical varicocele existence, the importance and necessity of CDUS examination could be seen. As the relation of varicocele with the infertility is documented well enough, while the reason for infertility is investigated, it is seen that CDUS is the only method to be preferred to make subclinical varicocele diagnosis ${ }^{3,15,20,22}$.

The reflux flow velocity and reflux duration together determine the amount of blood flowing backward ${ }^{18}$. The correlation between these two parameters indicates that if one of these values increases, the reflux flow volume will increase further. Thus, according to the accepted varicocele physiopathology, the possibility of affected spermatogenesis will be increased 13,28 .

One of the limitations of our study was the lack of follow-up of our patients. In particular, follow-up of patients who undergo surgery and the change in spermiogram values after surgery should be evaluated.
It has been observed that most of the previous studies do not distinguish between clinical and subclinical varicocele $\mathrm{e}^{14-19}$. It is seen that vein diameter is used radiologically as a varicocele criterion $^{20-23}$. In these studies, it has been reported that the varicocele stage increases as the vein diameter increases, It is reported that the probability of deterioration in spermiogram results increases as the stage increases. In this study, we aimed to investigate the development of negative effects on spermiogram results in subclinical varicocele cases that could not be detected by physical examination. In addition, we tried to find the most effective measure that can give an idea of sperm results by using other findings that can be obtained with CDUS examination and vein diameter measurement. Thus, in cases of infertility, we wanted to demonstrate the necessity of CDUS examination if the physical examination result is normal. We wanted to determine which measurements can be obtained with the CDUS examination to obtain valuable information about infertility. However, one of the most important limitations of our study was the small number of patients who were accepted as pathological spermiogram test. We could not find any relationship between reflux flow velocity and reflux duration and spermiogram results. However, we think that this result is not sufficient to reach a final judgment. We believe that in studies with more patients groups, valuable information about infertility can be obtained with reflux flow parameters. The relationship between reflux parameters and infertility will be useful in the treatment of infertility and in cases of surgical decision making.

In conclusion, we couldn't find any statistically significant relationship between anomaly in semen analysis and CDUS parameters we obtained. However, we think that the relationship between the anomalies in semen analysis and the findings obtained in CDUS examination in subclinical varicocele cases, 
which is our aim of performing the study, cannot be excluded. We assume that studies that will be committed with a bigger group of people with anomaly in semen analysis, more satisfying information will be obtained.

Declaration of Conflicting Interests: The authors declare that they have no conflict of interest.

Financial Disclosure: No financial support was received.

\section{REFERENCES}

1. Spencer WG. Celsus de Medicina: with an English translation. Cambridge: Harvard University Press, 1938.

2. Noske HD, Weidner W. Varicocele a historical perspective. World J Urol. 1999; 17: 151-7.

3. Sakamoto H, Saito K, Shichizyo T, et al. Color Doppler ultrasonography as a routine clinical examination in male infertility. Int J Urol. 2006; 13: 1073-78.

4. Gat Y, Zukerman Z, Chakraborty J, Gornish M. Varicocele, hypoxia and male infertility. Fluid Mechanics analysis of the impaired testicular venous drainage system. Hum Reprod. 2005; 20: 2614-19.

5. Trussell JC, Haas GP, Wojtowycz A, Landas S, Blank W. High prevalence of bilateral varicoceles confirmed with ultrasonography. Int Urol Nephrol. 2003; 35: 115-8.

6. World Health Organization. The influence of varicocele on parameters of fertility in a large group of men presenting to infertility clinics. Fertil Steril. 1992; 57: 1289-93.

7. Kroese ACJ, de Lange NM, Collins J, Evers JLH. Surgery or embolization for varicoceles in subfertile men. Cochrane Database of Systematic Reviews. 2012; 10: CD000479.

8. Marmar JL, Agarwal A, Prabakaran S, et al. Reassessing the value of varicocelectomy as a treatment for male subfertility with a new meta-analysis. Fertil Steril. 2007; 88: 639-48.

9. Abdel-Meguid T, Al-Sayyad A, Tayib A, Farsi HM. Does varicocele repair improve male infertility? an evidencebased perspective from a randomized, controlled trial. Eur Urol. 2011; 59: 455-61.
10. World Health Organization: Laboratory manual for the examination and processing of human semen, 5th ed. Geneva: WHO Press, 2010.

11. Trum JW, Gubler FM, Laan R, van der Veen F. The value of palpation, varicoscreen contact thermography and colour Doppler ultrasound in the diagnosis of varicocele. Hum Reprod. 1996; 11: 1232-35.

12. EAU (2010) EAU Guidelines edition presented at the 25th EAU Annual Congress: EAU Guidelines Office, Arnhem, The Netherlands.

13. Gorelick JI, Goldstein M. Loss of fertility in men with varicocele. Fertil Steril. 1993; 59: 613-6.

14. Hoekstra T, Witt MA. The correlation of internal spermatic vein palpability with ultrasonographic diameter and reversal of venous flow. J Urol. 1995; 153: 82-4.

15. Cina A, Minnetti M, Pirronti T, et al. Sonographic quantitative evaluation of scrotal veins in healthy subjects: normative values and implications for the diagnosis of varicocele. Eur Urol. 2006; 50: 345-50.

16. Orda R, Sayfan J, Manor H, Witz E, Sofer Y. Diagnosis of varicocele and postoperative evaluation using inguinal ultrasonography. Ann Surg. 1987; 206: 99101.

17. Schiff JD, Li PS, Goldstein M. Correlation of ultrasoundmeasured venous size and reversal of flow with Valsalva with improvement in semen-analysis parameters after varicocelectomy. Fertil Steril. 2006; 86: $250-2$.

18. Kocakoc E, Serhatlioglu S, Kiris A, et al. Color Doppler sonographic evaluation of inter-relations between diameter, reflux and flow volume of testicular veins in varicocele. Eur J Radiol. 2003; 47: 251-6.

19. Wolverson MK, Houttuin E, Heiberg E, Sundaram M, Gregory J. High-resolution real-time sonography of scrotal varicocele. AJR Am J Roentgenol. 1983; 141: 775-9.

20. Caskurlu T, Tasci AI, Resim S, Sahinkanat T, Ekerbicer $\mathrm{H}$. Reliability of venous diameter in the diagnosis of subclinical varicocele. Urol Int. 2003; 71: 83-6.

21. Hussein AF. The role of color Doppler ultrasound in prediction of the outcome of microsurgical subinguinal varicocelectomy. J Urol. 2006; 176: 2141-5.

22. Jarow JP, Ogle SR, Eskew LA. Seminal improvement following repair of ultrasound detected subclinical varicoceles. J Urol. 1996; 155: 1287-90. 
23. Liguori G, Trombetta C, Garaffa G, et al. Color Doppler ultrasound investigation of varicocele. World J Urol. 2004; 22: 378-81.

24. Arslan H, Sakarya ME, Atilla MK. Clinical value of power Doppler sonography in the diagnosis of varicocele. J Clin Ultrasound. 1998; 26: 229.

25. Gonda RL, Jr., Karo JJ, Forte RA, O’Donnell KT. Diagnosis of subclinical varicocele in infertility. Am J Roentgenol. 1987; 148: 71-5.

26. Chiou RK, Anderson JC, Wobig RK, et al. Color Doppler ultrasound criteria to diagnose varicoceles: correlation of a new scoring system with physical examination. Urology. 1997; 50: 953-6.
27. Dubin L, Amelar RD. Varicocele size and results of varicocelectomy in selected subfertile men with varicocele. Fertil Steril. 1970; 21: 606-9.

28. Vivas-Acevedo G, Lozano JR, Camejo MI. Effect of Varicocele Grade and Age on Seminal Parameters. Urol Int. 2010; 85: 194-9.

29. Libman J, Jarvi K, Lo K, Zini A. Beneficial effect of microsurgical varicocelectomy is superior for men with bilateral versus unilateral repair. J Urol. 2006; 176: 2602-5.

30. Richardson I, Nagler HM. Is bilateral varicocele more detrimental to male fertility than unilateral varicocele? Nat Clin Pract Urol. 2007; 4: 366-7. 